УДК 371.315.6:371.3(378)

Лариса Левицька,

Національний університет оборони України імені Івана Черняховського

ORCID ID 0000-0001-6575-9964

DOI: $10.33099 / 2617-1775 / 2021-02 / 115-120$

\title{
ВИМОГИ ДО МОДЕЛІ СИСТЕМИ ЗБОРУ ТА ОБРОБКИ ІНФОРМАЦІЇ ЩОДО ОЦІНЮВАННЯ ЯКОСТІ ВІЙСЬКОВОЇ ОСВІТИ
}

Розглянуто вимоги до моделі системи збору та обробки інформації щуодо оцінювання якості військової освіти. Визначено можливості та перспективи впровадження імплементації стандартів НАТО у вітчизняній системі військової освіти для вирімення завдання щзоо розробки сучасної моделі системи збору і оброки інформації. Розглянуто елементи моделі системи оцінювання якості щзодо їх відповідності сучасним запитам та очікуванням стейкхолдерів, які орієнтуються на принциии та підходи до оцінювання на основі стандартів краӥн-членів НАТО.

Ключові слова: військова освіта; модель; очінювання якості освіти; система військової освіти; стандарти НАТО; система збору та обробки інформації.

Постановка проблеми. Одним 3 важливих елементів сучасної системи військової освіти є оцінювання якості. Втім, система оцінювання якості, яка існує сьогодні, не відповідає сучасним запитам та очікуванням стейкхолдерів, які орієнтуються на принципи та підходи оцінювання, визначені в якості стандартів у країнах-членах НАТО й здійснюється у межах автоматизованих систем збору та обробки освітньої інформації. Розробка та впровадження у практику таких систем у вітчизняній системі військової освіти, як єдиного комплексу, застосування якого спрямоване на забезпечення високої якості освіти та підготовки офіцерів та військових фахівців, залишається актуальним питанням, яке потребує вирішення. Пріоритетом у даному випадку $\epsilon$ обгрунтування вимог до моделі системи збору та обробки інформації щодо оцінювання якості військової освіти за стандартами НАТО.

Метою статті $\epsilon$ визначення вимог до моделі системи збору та обробки інформації щодо оцінювання якості військової освіти відповідно до стандартів HATO.

Методи дослідження. У статті використано систему загальнонаукових i спеціальних методів теоретичного та емпіричного дослідження (аналіз наукової літератури з досліджуваної проблеми, систематизація та узагальнення, логічнопорівняльний методи, системний підхід, контент-аналіз).

Виклад основного матеріалу. Використання у ході наукових досліджень різноманітних моделей сприяє більш глибокому вивченню та усвідомленню наукової проблеми що досліджується. Процес моделювання, вибір і процеси побудови моделі та визначення вимог до їі розроблення, являється невід'ємним елементом більшості наукових досліджень. У науці виділяють низку моделей, які відрізняються за способом відображення дійсності (результатів 
моделювання). За способом відображення дійсності до основних видів моделей відносяться евристичні, натуральні та математичні [1-4].

До евристичних моделей відносяться моделі, які собою представляють образи, що формуються в уявленні людини. Опис цих моделей здійснюється зрозумілою та простою людською мовою. Ці моделі, як правило, не формалізуються, тобто не підлягають опису 3 використанням формальнологічних та математичних виразів (символічна мова), а їх використання у своїй більшості здійснюється на початкових етапах того чи іншого наукового дослідження у випадку, коли дані про проблематику, що досліджується, $є$ суттєво обмеженими або неповними. На наступних етапах досліджень ці моделі конкретизуються, ускладнюються та уточнюються.

Основною відмінністю натуральних моделей $\epsilon$ їх правдоподібність, адекватність реально існуючим системам. Натуральні моделі є матеріальними, характеризуючись іншими, ніж у інших моделей, розмірами та кількістю елементів самої моделі.

Найбільш універсальними $є$ математичні (формалізовані) моделі, які найчастіше використовуються у наукових дослідженнях. Це обумовлено тим, що використання саме математичної моделі дозволяє поставити "чистий експеримент", тобто, в певних рамках щодо точності моделювання, дослідити вплив того чи іншого окремого перемінного параметру в умовах постійності інших параметрів, виявити спроможності щодо подальшого прогнозування розвитку явищ чи процесів, спроможності вишукувати різні способи управління ними тощо.

Загалом, математичні моделі $є$ формалізованими, тобто вони являють собою сукупність взаємопов'язаних математичних i формально-логічних виразів, як правило, таких, що відображають реальні процеси і явища та $\epsilon$ основою для побудови у подальшому коп'ютерних моделей і застосування обчислювальної техніки. На теперішній час, такі моделі в основному реалізуються у вигляді програмних комплексів з наявним пакетом програм для проведення відповідних обчислень на ПЕОМ. За формою свого представлення математичні моделі поділяються на аналітичні, інформаційні, чисельні та формально-логічні.

Різні сфери, до наукового аналізу яких застосовуються моделі, зокрема, математичні, висувають різні вимоги, які визначають характеристики тієї чи іншої моделі. Це стосується і процесів розроблення конкретних моделей, адже вважається, що значимість вимог є “критичною величиною" для успішної розробки того чи іншого проекту в процесі наукового дослідження.

3 точки зору аналізу моделей системи оцінки якості військової освіти доцільно звернути увагу на загальноприйняті в науці вимоги до розроблення та функціонування моделей, а саме [3-5]:

- адекватність моделі - тобто, спроможність вибраної моделі до вирішення (розв'язання) поставлених завдань;

- точність в отриманні результатів моделювання - відповідність ступеню отриманих результатів з раніше встановленими чи бажаними; 
- універсальність моделі - можливість використання моделі для розширення кола завдань дослідження;

- доцільна економічність моделювання - адекватність отриманих результатів моделювання з фінансовими затратами.

У ході первинної оцінки інформації визначається ступінь необхідності отриманих даних потребам освітньої діяльності, критерієм чого є релевантність (релевантність інформаціі), тобто наявність зв'язку з проблемою (відповідність наявним потребам) і здатність інформації зробити внесок у процес розуміння проблеми. Якщо інформація потенційно може допомогти у виконанні завдань освітньої діяльності та досягненні поставленої мети, то вона становить для фахівця-аналітика інтерес та є релевантною.

Похідна оцінка якості військової освіти може бути здійсненою за допомогою низки критеріїв: достовірності, адекватності, повноти й оптимальності, точності, оперативності (своєчасності надходження) тощо. Це визначає певну сукупність даних, які аналізуються, формуючи певні аналітичні блоки за визначеними параметрами та критеріями, зокрема $[1 ; 2 ; 5]$ :

- достовірність інформації передбачає визначення ступеню об'єктивного, точного відображення подій, фактів, що відбулися в системі військової освіти та у процесі здійснення освітньої діяльності. Достовірність характеризується такими параметрами: наявність підтвердження 3 інших джерел інформації; стикування 3 іншою інформацією; професійний рівень аналітика та його вмотивованість; розгалуженість системи інформаційноаналітичного забезпечення освітнього процесу та рівень представленості в ній інтересів всіх стейкхолдерів; властивості каналів передачі інформації тощо;

- адекватність інформації дозволяє оцінити ступінь повноти, цілеорієнтованості та якості отриманої інформації;

- повнота й оптимальність інформації передбачає визначення ступеню відповідності обсягу отриманої інформації достатньому обсягу необхідних даних для раціонального та оптимального вирішення конкретного завдання. Повнота й оптимальність інформації характеризується ступенем достатності отриманої інформації для розуміння ситуації, що склалася, особливостей процесу прийняття управлінського рішення та його імовірних наслідків;

- точність інформації визначається ступенем об’єктивно вірного (адекватного) віддзеркалення події, явища, стану об'єкта, його оточення. Точність інформації характеризує міру іï деталізації, наближення до конкретної дійсності, яка може бути верифікованою;

- оперативність (своєчасність надходження) інформації визначається ступенем відповідності часу отримання інформації реальному часу здійснення конкретного процесу освітньої діяльності;

- лаконічність інформації визначається ступенем точності змісту інформації та співвідношенням її обсягу (мінімальності) насиченості;

- логічність інформації визначається ступенем послідовності викладення даних за умов збереження змісту, сенсу і форми вираження для однакового іï розуміння; 
- значимість інформації визначається ступенем важливості отриманої інформації для використання ії у вирішенні поставлених завдань;

- цінність (корисність) інформації визначається ступенем можливості отриманих відомостей процесу планування подальших або поточних коригувальних заходів. Величина цінності інформації виражається через приріст вірогідності досягнення освітньої мети до і після отримання зворотної інформації;

- відповідність інформації визначеній меті визначається ступенем відповідності за рівнем координації та субординації, сукупність яких утворює ієрархію цілей, при чому, як правило, пріоритетом у практиці освітньої діяльності користується реалізація головних цілей;

- систематизованість і комплексність інформації визначається ступенем відповідності отриманих даних групі однорідних даних за певними ознаками 3 всієї сукупності даних, сформованих у певну ієрархічну єдність;

- новизна інформації визначається ступенем невідповідності даних отриманої (зворотної) інформації щодо якості військової освіти та освітнього процесу в цілому.

Таким чином, фахівцем-аналітиком може бути встановлено обгрунтування та доцільність прийнятих управлінських рішень у сфері освітньої діяльності 3 метою підвищення ефективності виконання цільових завдань, визначених стейкхолдерами, ступеня досягнення бажаних результатів тощо.

У свою чергу, аналіз сучасних досліджень вказує на те, що основними вимогами, які у цілому сприятимуть досягненню цілей, завдань, об'єктивному оцінюванню якості військової освіти та створення умов (за усіма існуючими видами забезпечення навчально-виховного процесу у ВВН3 [1-3]) щодо реалізації програмних результатів у рамках функціонування системи військової освіти на етапі моделювання системи збору та оцінки інформації, $\epsilon$ [2; 3; 5]:

- спроможність моделі щодо реалізації автоматизованого об'єктивного оцінювання якості освіти;

- спроможність моделі щодо реалізації автоматизованого визначення відповідності змісту та результатів військової освіти вимогам встановлених стандартів.

У наведеному прикладі йдеться про формування моделі оцінки якості військової освіти відповідно діючим стандартам як національної системи військової освіти, так і стандартам НАТО. Впровадження стандартів НАТО до оцінки якості військової освіти у національній системі військової освіти $\epsilon$ необхідним елементом, якій має бути обов'язково врахований під час розроблення системи збору і обробки інформації. Такий підхід дає можливість забезпечити стейкхолдерів необхідною інформацією для забезпечення ефективності процесу освіти та підготовки офіцерів і військових фахівців на основі оцінки якості військової освіти. При цьому стейкхолдери отримують можливості оперативного і гнучкого усунення наявних недоліків в освітніх програмах,що вимагає застосування сучасних принципів до побудови моделі системи збору і обробки інформації. 


\section{Висновки та перспективи подальших досліджень.}

Необхідність урахування специфічних вимог до розроблення моделі, результати аналізу використання систем СЗОІ щодо оцінювання якості освіти випускників ВВНЗ за підсумками їх службової діяльності у Збройних Силах України та збройних силах держав-членів НАТО, нормативно-правових актів (документів) 3 питань набуття військової освіти в Україні, у т.ч. офіційних документів НАТО щодо набуття професійної військової освіти військовими фахівцями збройних сил альянсу, а також можливостей щодо обчислення рівнів сформованості у випускників ВВНЗ відповідних компетентностей та визначення ступеня їх відповідності тому чи іншому професійному стандарту 3 метою винайдення наукового підходу до обгрунтування вимог до автоматизованої інформаційної системи збору та обробки інформації та досягнення мети дослідження потребує обрання аналітичної інформаційної моделі. Проте, це питання потребує подальших досліджень.

\section{ЛІТЕРАТУРА}

1. Горбачевський С.К. Інформаційна система оцінки професійних компетентностей офіцерів - випускників вищих військових навчальних закладів тактичного рівня / // Військова освіта. - 2020. - № 2(42). - С. 120-129.

2. Горячев А. Практикум з інформаційних технологій. - М.: Лабораторія базових знань, 1999. - 272 с.

3. Інноваційний розвиток вищої військової освіти України: моногр. / Кол. авт. Харків: Цифрова друкарня № 1, 2012. - 456 с.

4. Лондар С.Л. Міжнародний досвід розвитку сучасних освітніх інформаційних систем / С.Л. Лондар // Освітня аналітика України. - 2018. - № 1(5). - Режим доступу. - URL: http://science.iea.gov.ua/wp-content/uploads/2019/09/1_2019.pdf. (дата звернення: 26.06.2020).

5. Полторак М.Ф. Особливості використання систем збору та обробки освітньої інформації з питань оцінювання якості військової освіти у Збройних Силах України та збройних силах НАТО: порівняльний аналіз / М.Ф. Полторак // Військова освіта. - 2021. № (43). - C.254-266.

\section{REFERENCES}

1. Gorbachevsky S.K. Information system for assessing the professional competencies of officers - graduates of higher military educational institutions of the tactical level / // Military Education. - 2020. - № 2 (42). - P. 120-129.

2. Goryachev A. Workshop on information technology. - M .: Laboratory of basic knowledge, 1999. - $272 \mathrm{p}$.

3. Innovative development of higher military education in Ukraine: monograph. / Qty. aut. Kharkiv: Digital Printing House № 1, 2012. - 456 p.

4. Londar S.L. International experience in the development of modern educational information systems / S.L. Londar // Educational Analytics of Ukraine. - 2018. - № 1 (5). - Access mode. - URL: http://science.iea.gov.ua/wp-content/uploads/2019/09/1_2019.pdf. (appeal date: 26.06.2020).

5. Poltorak M.F. Peculiarities of using systems for collecting and processing educational information on assessing the quality of military education in the Armed Forces of Ukraine and the NATO Armed Forces: a comparative analysis / M.F. Poltorak // Military education. - 2021. № (43). - P.254-266. 


\section{PEЗЮME}

Лариса Левицкая,

Национальный университет обороны Украины имени Ивана Черняховского

Рассмотрены требования к модели системы сбора и обработки информации по оценке качества военного образования.

Определены возможности и перспективы внедрения стандартов НАТО в отечественной системе военного образования для решения задачи разработки современной модели системы сбора и оброки информачии.

Рассмотрены элементы модели системы оценки качества по их соответствию современным запросам и ожиданиям стейкхолдеров, которые ориентируются на принципь и подходы к оченке на основе стандартов стран-членов НАТО.

Ключевые слова: военное образование; модель; оченка качества образования; система военного образования; стандарты НАТО; система оружия и обработки информаџии.

\section{SUMMARY}

\section{Larisa Levitska,}

National Defense University of Ukraine named after Ivan Cherniakhovskyi,

\section{Requirements to the model of the system of collection and processing the information regarding the quality assessment of military education}

The requirements to the model of the system of collecting and processing information for assessing the quality of military education are considered. Possibilities and prospects for the implementation of NATO standards in the domestic military education system to address the problem of developing a modern model of information collection and processing system have been identified. The elements of the model of the quality assessment system in relation to their compliance with modern demands and expectations of stakeholders, which focus on the principles and approaches to assessment based on the standards of NATO member countries, are considered.

Key words: military education; model; education quality assessment; military education system; NATO standards; system of weapons and information processing. 